\title{
Economic sociology
}

(c) 2021 г.

\author{
M.A. SHABANOVA
}

\section{SEPARATE WASTE COLLECTION AS RUSSIANS' VOLUNTARY PRACTICE: THE DYNAMICS, FACTORS AND POTENTIAL}

Marina A. SHABANOVA, Dr. Sci. (Soc.), Prof., Leading Researcher, Center for Studies of Civil Society and the Nonprofit Sector, National Research University Higher School of Economics, Moscow, Russia (mshabanova@hse.ru).

\begin{abstract}
The paper presents the data of three all-Russia representative surveys (2014, 2017 and 2020) on the dynamics of the levels, factors and conditions of citizens' engagement in the practice of separate household waste collection (SWC). It has been ascertained that today a major (and increasingly growing) share of Russians do not reject their engagement in SWC but put forward a counter-demand for an available and convenient infrastructure and information in this sphere. The progress in the development of an enabling environment in 2019-2020 had an impact on the sharp increase in the number of actual SWC participants, a growing number of potential participants and a drastic decline of those who are indifferent, which somehow mitigated adverse impact of the waste problem owing to the pandemic. The study provides evidence that despite the persistence of key motivations and factors of engagement in SWC, significant changes occurred in their structure in 2020 resulting from the waste reform, change in the quality structure of participants and the pandemic challenge. Based on the new wave of the survey, the paper makes a conclusion about the potential and measures for further enhancement of Russians' participation in SWC.

Keywords: waste issue - civil society • separate collection of household waste • environmental consumer responsibility • pro-environmental behavior $\bullet$ ethical consumption $\bullet$ COVID-19 pandemic

DOI: $10.31857 / S 013216250016788-9$

This article is a translation of: Шабанова М.А. Раздельный сбор бытовых отходов как добровольная практика россиян: динамика, факторы, потенциал // Sotsiologicheskie Issledovaniia. 2021. No 8: 104-117. DOI: 10.31857/S013216250015256-4
\end{abstract}

Introduction. The severity of the waste issue in Russia is on the rise. It is manifested by congestion of existing landfills, reproduction of unauthorized landfills, increase in the volume and appearance of new types of waste amid the pandemic, discontent and public protests against dumping, etc. The experience of countries that have had a great progress in solving the waste issue over the past two or three decades indicates that recycling with pre-sorting of waste into different fractions is the most effective and safe way to deal with waste [Hoornweg, Bhada-Tata, 2012: 27]. In Russia, the separate collection of household waste (SCHW) remains a purely voluntary practice of civil society (CS): it is promoted mainly by pro-environmental and pro-social grounds, it is associated with additional efforts and time costs on the part of participants, but is not accompanied by any incentives or sanctions. The boundaries of this sphere of the civil society are constantly changing and depend on the actions of other concerned parties, as well as on trigger events. The specifics of 2020 consists in the simultaneous impact of two 
differently directed processes on the participation of Russians in the SCHW: active promotion by the government and business of the conditions for the SCHW and COVID-19 pandemic that complicated this promotion.

Amid the pandemic, the conditions for participation of all actors in the reform of this sphere have become more complicated: firstly, the volume of garbage in the residential sector has increased (according to regional operators, averagely by one third) ${ }^{1}$, new types of garbage (masks, gloves) have appeared; and secondly, consumer preferences have changed. Among them there are unwillingness to bring household waste to separated containers due to the fear of infections in the elevator; increased consumption of antibacterial wet wipes and products, disposable bags; rapid growth of online purchases, and, accordingly, packaging materials, etc. In addition, the pandemic has suspended the work of companies and charitable organizations that take away (accept as a gift) unnecessary items/things, free transfer or peer-to-peer sales of used things or other items. The volume of garbage thrown out has also increased in connection with general cleaning and repairs of apartments/houses, which were pushed by forced isolation. In some countries, the researchers have recorded an increase in demand for new products due to the fact that the second hand stores are closed and are usually not present on the Internet [lkiz et al., 2021]. The experts predict that a number of new consumer habits will continue after the pandemic [Giudice et al., 2020; Hobbs, 2020].

How do these changes, which have complicated the implementation of the garbage reform in Russia, overlap with the steps taken (since the beginning of 2019) by the government and business in developing a favorable environment for SCHW? Which of the effects was stronger? Have there been any advances in involving Russians in the SCHW by the end of 2020 in comparison with the pre-pandemic period, when the situation practically did not change? How have the social potential, motives, factors and conditions for involving in the SCHW changed? Without an answer to these questions, it is impossible to understand the prospects for SCHW development in the Russian institutional and cultural environment as well as the degree of civil society involvement, without knowledge of which it is impossible to fully assess the economic significance of the latter. The goal of the research is to identify the dynamics $(2014,2017,2020)$ of the levels, factors and conditions of Russians'actual and potential involvement in the SCHW as a voluntary practice of the civil society, and also to justify on this basis the measures for further expansion of the SCHW.

Theoretical perspectives and extant research. In Russia, the SCHW, while remaining a voluntary choice of the civil society, essentially reflects what $M$. Micheletti calls an individualized collective action [Micheletti, 2003]. Individuals from different social groups, outside of membership in any civil associations or parties, on their own initiative take responsibility for a problem that they consider socially important. They devote more time and make more efforts, alone or together with others, promoting the solution of an urgent problem in their understanding. This type of activity allows self-realization, combining personal interest and the common good [ibid: 25-26]. This everyday activism, which is based not on given (structural), but on flexible (contextual) identities embedded in specific situations, occurs in a variety of spheres. Ethical consumption, including ethical handling of household waste, is one of them.

To understand the real patterns of the formation of voluntary pro-environmental /prosocial practices in a changing (due to both the activities of other actors and unexpected trigger events) external environment, it is advisable to integrate Micheletti's ideal construct (detached from structures) into the concepts that consider different aspects of the connections between the levels of social reality - subjects/actions and structures. This allows us to supplement the theoretical understanding of the subject of research with the following main propositions.

Two levels of social reality (structures and subjects) are closely connected with each other and at the same time retain a certain degree of autonomy. When analyzing social shifts, each

${ }^{1}$ Garbage removal operators in the regions faced an increase in waste // TASS. 2020. April 6. URL: https://tass.ru/obschestvo/8170091 (reference date: 17.06.2021). 
level is considered in two incarnations, in potency and in reality, and the vector of changes is given a probabilistic character [Shtompka, 1996; Zaslavskaya, 2004]. The level of SCHW development as a voluntary choice of the civil society, as well as the degree (pace) of its transition from a potency to a reality at each moment of time reflect both the degree of the civil society concern about the problem, and the balance of forces between the main concerned parties (government, business, non-profits, population, etc.), their interests and resources. Up to a certain point, the initiatives and requests of the population and non-profits may not find a response from the authorities, and likewise the progress of the latter in the garbage reform may not be noticed by mass groups of the population. Reducing failures in the information signals is a field of activity of all interested parties (non-profits, mass media, authorities, etc.), in order not to bring the situation to "garbage riots", protests against dumping, to which the authorities are forced to respond promptly, but belatedly.

Studies on the factors of population involvement in SCHW held in different countries (for more information, see: [Shabanova, 2019]) indicate the importance of both the pro-environmental /prosocial attitudes of individuals, their moral and cultural aspirations, and the level of the favorable environment: accessible and convenient infrastructure, education and information, material incentives and sanctions, social pressure and forcing, etc. (see, for example: [Miafodzyeva, Brandt, 2013; Kirakozian, 2016; Iyer, Kashyap, 2007; Robinson, Read, 2005; Shaw, Maynard, 2008; Owusu et al., 2013; Czajkowski et al., 2017] etc.). All these factors affect the ratio between the costs and benefits of involvement in the SCHW, as well as the size of the gap between intentions and actual actions, in a word, the parameters of individualized collective actions about the garbage problem.

Following Etzioni, we proceed from the fact that the individuals simultaneously have two types of aspirations, egoistic, on one hand as well as moral and cultural, on the other, which can be in conflict with each other. This leads to various kinds of adverse consequences (feelings of guilt, shame, etc.) [Etzioni, 2003], ultimately reducing the level of subjective well-being of individuals. In other words, we do not strictly oppose the altruistic and egoistic involvement of individuals in the $\mathrm{SCHW}$, but proceed from the fact that their real actions at any given time reflect a certain trade-off between two types of aspirations. There is a reason to believe that it differs greatly among the representatives of different waves of participants of the SCHW: pioneer enthusiasts tend to make greater sacrifices than the representatives of subsequent waves. It is no accident that our research has shown that as compared to actual participants, the potential ones have higher requirements for accessing SCHW [Shabanova, 2019].

The pandemic has made adjustments to the factors of population involvement in the $\mathrm{SCHW}$ and other "near-garbage" practices. The first studies conducted in different countries record an increase in the volume of garbage in households [Hantoko et al., 2021], associated with a sudden change in everyday lifestyle, fears and concerns for health, an active transition to online shopping, etc. As a result, there is an increase in plastic and medical waste. Thus, according to an international study, $45-48 \%$ of respondents indicated an increase in the consumption of packaged goods, fresh food and food delivery; plastic packaging increased by $45 \%$ [Filho et al., 2021]. Regarding the volume of food waste, the results are contradictory, but most state either their preservation at the same level, or a reduction amidst the pandemic [UNSCN, 2020; Principato et al., 2020; Pappalardo et al., 2020] and, as a result, a change in the garbage structure. Sudden shifts in the volume and structure of garbage have become a serious challenge for the waste management system in all countries, but especially in low and middle income countries, where ethical consumption practices are poorly developed, and the $\mathrm{SCHW}$ is breaking new ground or [is] absent. In Russia, active steps to promote the garbage reform fell on the COVID year, which, in case of a positive response from the civil society, could at least partially smooth out the garbage problem that has worsened amidst the pandemic. But how did the population react? Has the individualized collective action aimed at solving this problem become more apparent? 
Based on extant research and our previous studies, we will proceed from the fact that the progress made in 2019-2020 in the development of a favorable SCHW environment, despite the pandemic, has resonated with the population affecting both the level and structure of factors conducive to accessing this practice. At this stage, the following hypotheses were tested.

H1: Assessment of the level of development of the favorable environment currently play a more important role in accessing SCHW than all the components of the "green moral index" (pro-environmental /prosocial motives and attitudes that reflect the aspirations of individuals to contribute to the common good, to bear personal responsibility for the state of the environment).

H2: Pro-environmental /prosocial motives are more associated with the probability of actual involvement in the SCHW than the motives of personal gain, economic and non-economic (special satisfaction from participation, creating the impression a responsible person), although the role of the latter is rather increasing.

H3: The factors of getting into groups with different position in relation to the SCHW have specifics. If the probability of getting into the group increases significantly among the actual participants with an increase in the estimates of the favorable environment development, this is rather not the case among the potential participants. The potential participants, in contrast to the actual ones, make higher requests for the immediate, comprehensive development of the favorable environment as a condition for accessing the $\mathrm{SCHW}$, which reduces the costs and increases the effectiveness of their participation (the efforts made are not useless).

H4: The level of concern about the severity of the garbage problem in Russia is positively associated with the probability of getting into the groups of both actual and potential participants. Such a dependence is also characteristic of the position regarding the SCHW as a way to weaken the garbage problem, although the connection with the probability of inclusion in the SCHW is not so strong.

H5: Since the SCHW in Russia is currently a purely voluntary practice, the involvement in other voluntary socio-economic activities that characterize the degree of "social response" (monetary donations, voluntary labor, transfer of things) is positively associated with the probability of participation in SCHW.

Data and methods. The study is based on data from three surveys (2014, 2017, 2020 for 2 thousand people), representing the population of Russia by gender, age and level of education ${ }^{2}$. Having no data on the level of involvement of Russians in the SCHW in 2019, we will be guided by the following considerations to understand the impact of two differently directed processes in 2020 (a rapid change in the infrastructure development and a pandemic that complicated the implementation of the garbage reform). The slow change in the level of infrastructure development had almost no effect on the level of involvement in the SCHW: 11 and $13 \%$, respectively, in 2014 and 2017 . Since there were no fundamental steps in changing the environment until 2019, we will proceed from the persistence of the tendency and an approximate estimate of $15-16 \%$ in 2019 , i.e. on the eve of a pandemic.

Along with the descriptive analysis aimed at identifying the dynamics of the composition of groups with different attitudes to the $\mathrm{SCHW}$, the multinomial logit-regression apparatus was used to assess the relationships between different factors and inclusion of individuals in these groups (data as of November 2020). The dependent variable took three possible values: 1 - actual participant of SCHW, 2 - a potential participant, 3 - an individual indifferent to this practice (base group for comparison).

Dynamics, motives and conditions of population's involvement in the SCHW. Since in the first two waves of monitoring $(2014,2017)$ the share of SCHW participants practically did not change (Table 1), it was clear that the potential of pioneer enthusiasts was almost exhausted, and without creating a convenient and efficient infrastructure, the practice would not develop [Shabanova, 2019]. At the same time, even then, the coefficients of stability and

\footnotetext{
${ }^{2}$ Multistage stratified territorial random sampling. The survey method is a formalized.
} 
Participation and intentions to join/continue participating in the SCHW in the next year or two (in \%)

\begin{tabular}{l|c|c|c}
\hline \multicolumn{1}{c|}{ Indicator } & 2014 & 2017 & 2020 \\
\hline Currently participate on a regular basis & 11 & 13 & $34(27)^{*}$ \\
Intend to join or continue to participate in the next year or two & 23 & 29 & $54(47)^{* *}$ \\
Stability coefficient *** & 73 & 81 & 82 \\
Replacement coefficient **** & 5.1 & 7.8 & 4.63 \\
Distribution by type: & & & \\
participate and will continue to participate & 8 & 10 & 28 \\
do not participate, but intend to & 15 & 19 & 26 \\
participate, but intend to stop & 3 & 2.5 & 6 \\
do not participate and do not intend to & 74 & 68 & 40 \\
Total & 100 & 100 & 100
\end{tabular}

Notes. ***Taking into account both those who put (intend to put) waste to separate containers near the house, and those who bring (intend to hand over) their individual types (waste paper, plastic, glass, metal, etc.) to special points (in parentheses - only the first group). *** Stability coefficient means the ratio of the number of those who intend to continue participating in separate garbage collection in the next year or two to the total number of those currently involved in this practice (. 100\%). $* * * *$ The replacement coefficient is the ratio of the number of those who intend to join this practice to the number of those who intend to abandon it in the next year or two.

substitution signaled a good (and expanding) social base for the development of SCHW, about high chances of increasing the number of participants in case of the development of a favorable environment. A jump in the growth of the share of SCHW participants detected at the end of 2020 (Table 1) reflects the reaction of the population to positive changes in the development of infrastructure: first of all, to the installation of separate containers for recyclable materials in courtyards from 2019. The sharp increase in the number of actual participants at the expense of potential ones, who, as we found earlier, have high requirements for the conditions of inclusion into the SCHW, also affected the growth of the share of those who were disappointed (6\% in 2020 compared to $2.5 \%$ in 2017 . This rollback can be associated both with the insufficient quality of the SCHW infrastructure that has become available, and with the effect of the pandemic, which has pushed concerns over the garbage problem to the background.

As a result, currently the share of actual participants of the SCHW reaches $34 \%: 27 \%$ - sort and carry household waste into specially installed separate containers near the house, $12 \%-$ sort and hand over certain types of waste (waste paper, plastic, glass, metal, etc.) to special reception points, and $5 \%$ are included in both practices. The share of potential participants (we included those who are not currently included in the SCHW, but intend to do it in the next year or two) is $26 \%$, and the share of indifferent participants (who do not participate now and do not intend to do it in the next year or two) is $40 \%$. The latter group is still numerous, but it is much smaller than in 2014 and 2017 (Table 1).

Groups with different position regarding the SCHW are not equally concerned about the garbage problem and have different attitudes to the need for SCHW to weaken it (Table 2). Actual and potential participants are much more concerned about the garbage problem, and they often associate its weakening with the SCHW. Among the indifferent people, on the contrary, the share of "not concerned" or not thinking about the garbage problem at all, as well as those who believe that Russians are not yet ready for the SCHW, is higher. At the same time, in all three groups, a very significant part (21-25\%), recognizing the importance of the problem, does not believe in the success of its solution, because all previous attempts have failed. 
Table 2

Concern about the garbage problem and the attitude to the introduction of the SCHW of different groups (in \%)

\begin{tabular}{|c|c|c|c|c|}
\hline Position & Actual & Potential & Indifferent & Total \\
\hline \multicolumn{5}{|c|}{ Personal concern about the garbage problem in Russia* } \\
\hline Very concerned & 46 & 44 & 28 & 38 \\
\hline Rather concerned & 40 & 39 & 35 & 38 \\
\hline Rather not concerned & 8 & 8 & 17 & 12 \\
\hline Not concerned at all & 2 & 4 & 12 & 6 \\
\hline Didn't think about it & 4 & 5 & 7 & 6 \\
\hline \multicolumn{5}{|c|}{ The need to introduce the SCHW in Russia: opinions } \\
\hline $\begin{array}{l}\text { "This is a priority, we need to create conditions for its } \\
\text { solution as soon as possible" }\end{array}$ & 60 & 49 & 30 & 45 \\
\hline $\begin{array}{l}\text { "I recognize the importance, but I do not believe in its } \\
\text { success. All previous attempts have failed" }\end{array}$ & 21 & 23 & 25 & 23 \\
\hline $\begin{array}{l}\text { "The problem is important, but our people are not yet } \\
\text { ready to separate household waste" }\end{array}$ & 16 & 23 & 30 & 23 \\
\hline $\begin{array}{l}\text { "Russia does not need a separate garbage collection } \\
\text { at all" }\end{array}$ & 3 & 2 & 8 & 5 \\
\hline Other/difficult to answer & 0 & 3 & 7 & 4 \\
\hline
\end{tabular}

Note. *The question was like this: "Now there is a lot of talk about the problem with garbage in Russia. Some consider it important because of the huge garbage dumps that poison the soil and air. Others are not concerned about it because of the lack of dumps near their locality. Still others say that there is no such problem, referring to the large territory of our country. To what extent are you personally concerned with the garbage problem in Russia?"

However, the actual and potential participants, sharing this position, probably hope that the current campaign to introduce the SCHW will be successful.

Among the motives for participation or readiness to start participating in the SCHW, proenvironmental/prosocial ones consistently and by solid margins lead, combined in a number of studies [Berglund, 2006] in the "green moral index": 88\% (2017) and 84\% (2020) of the respondents named at least one of its elements (Table 3). The structure of the index in 2020 has undergone changes: against the background of a decrease in the share of those who want to contribute to environmental improvement, well-being of current and future generations (in the group of real participants), as well as those who believe that it is economically beneficial for society (in all groups), the share of those who simply try to do what, in their opinion, everyone should do, has increased everywhere. The "green moral index" of the "indifferent people" has significantly decreased, however, today half of them have named at least one pro-environmental/prosocial motive for their possible participation in the SCHW. Therefore, as the favorable environment develops, we can still count on the involvement of a significant part of this group. The role of considerations of personal advantage (economic and especially non-economic) has increased (both for real and potential participants), but it is, as before, secondary (Table 3).

An disturbing fact is the decrease in the share of those who join or ready to join the $\mathrm{SCHW}$, because they believe that their efforts are not in vain and they can influence the solution of an important problem. Among the potential participants, this share decreased by almost 2 times (Table 3). Since the confidence in the effectiveness of one's efforts is a significant factor which is positively associated with the probability of getting into the group of potential participants [Shabanova, 2019], ceteris paribus, its decrease affects the increase in this group. This is probably due to a decrease in the replacement coefficient in 2020 (see Table 1).

Against the decrease in the group of indifferent people, among them the share of people who are very categorical about the SCHW has increased: $28 \%$ do not find either altruistic or 
Table 3

Motives for participation or readiness to start participating in the $\mathrm{SCHW}^{*}$ (in \% by column)

\begin{tabular}{|c|c|c|c|c|c|c|c|c|}
\hline \multirow{2}{*}{ Motives } & \multicolumn{2}{|c|}{ Actual } & \multicolumn{2}{|c|}{ Potential } & \multicolumn{2}{|c|}{ Indifferent } & \multicolumn{2}{|c|}{ Total } \\
\hline & 2017 & 2020 & 2017 & 2020 & 2017 & 2020 & 2017 & 2020 \\
\hline $\begin{array}{l}\text { 1. I want to feel like a responsible person for } \\
\text { the environment status }\end{array}$ & 47 & 49 & 35 & 46.5 & 21.5 & 18 & 27 & 36 \\
\hline $\begin{array}{l}\text { 2. I want to contribute to the environmental } \\
\text { improvement, well-being of current and } \\
\text { future generations }\end{array}$ & 36 & 29 & 29 & 37 & 21 & 20 & 24 & 28 \\
\hline $\begin{array}{l}\text { 3. I believe that this is economically beneficial } \\
\text { for society as a whole }\end{array}$ & 29 & 16 & 31 & 18 & 19 & 9 & 23 & 14 \\
\hline $\begin{array}{l}\text { 4. I try to do what, in my opinion, everyone } \\
\text { should do }\end{array}$ & 37 & 43 & 22 & 45 & 18 & 20.5 & 21 & 34 \\
\hline Total: at least one item from clauses $1-4$ & 88 & 84 & 80 & 88 & 60 & 50 & 67 & 72 \\
\hline $\begin{array}{l}\text { 5. I believe that my efforts are not in vain, and } \\
\text { I can influence the solution of an important } \\
\text { problem }\end{array}$ & 20 & 15 & 34 & 18 & 17 & 7 & 21 & 13 \\
\hline $\begin{array}{l}\text { 6. It is economically beneficial for me } \\
\text { personally (my family) }\end{array}$ & 10 & 14 & 9 & 11 & 8 & 8 & 8 & 11 \\
\hline $\begin{array}{l}\text { 7. I want to give people the impression of } \\
\text { myself as a responsible person }\end{array}$ & 4 & 15 & 4 & 9 & 4 & 3 & 4 & 8.5 \\
\hline Total: at least one item from clauses 6,7 & 14 & 25 & 11.5 & 18 & 10.5 & 10 & 11 & 17 \\
\hline $\begin{array}{l}\text { 8. I get special satisfaction from these actions, } \\
\text { I am pleased with involvement in that affair }\end{array}$ & 9 & 11 & 8 & 9 & 5 & 4 & 6 & 7.4 \\
\hline $\begin{array}{l}\text { 9. I do not participate and/or do not intend to } \\
\text { participate in separate garbage collection }\end{array}$ & 2 & 5 & 4.5 & 3.5 & 23 & 28 & 17 & 14 \\
\hline
\end{tabular}

Note. * The answer to the question "Please tell us the main reasons why you are already participating or are ready to start participating in separate garbage collection" (any number of answers allowed). Adapted and supplemented question from: [Berglund, 2006: 564].

selfish reasons for involvement in the SCHW ("I am not interested in this") and do not intend to voluntarily sort waste.

The main constraint for involvement in the SCHW is the lack of an accessible and convenient infrastructure. So, regarding the availability of containers for separate waste collection near the house, the position "there are no conditions at all" was chosen by $59 \%$ of potential and $67 \%$ of indifferent ones against $35 \%$ of real ones. Such a nature of differences is reproduced by the assessment of the reasonable amount of time for the waste delivery to special points or separate containers (Table 4). Attention is drawn to the low satisfaction of even real participants with the level of awareness about what and how it can be sorted and how to do it correctly. The score of 1-2 points on a 5-point scale was given by $62 \%$ of real participants, $77 \%$ by potential and $81 \%$ by indifferent ones. According to the share of those who received the lowest scores, the awareness is ahead of all other components of the favorable environment, regardless of the position of individuals in relation to the SCHW. According to the total estimate of four components of the favorable environment, $58 \%$ of actual participants of the SCHW scored the positions not lower than the average, compared to $34 \%$ and $23 \%$ among potential and indifferent ones, respectively.

Even if the main part of Russians is ready to sort waste, then without additional inconveniences (Table 5). Among the conditions of inclusion (or continued participation), as before, the installation of containers for the SCHW near the house is leading by a significant margin (64\%). The availability of information about what and how you can sort; how to do it correctly $(30 \%)$ takes the second place. The factors that characterize the quality of accessibility structure (timely export, recycling, etc.) play a noticeable, but more modest role than before. Probably, the steps taken by the government and business to promote the garbage reform affect the 
Assessment by different groups of conditions for the development of SCHW in their locality (in \% by column)

\begin{tabular}{|c|c|c|c|c|}
\hline Conditions & Actual & Potential & Indifferent & Total \\
\hline \multicolumn{5}{|c|}{ Availability of containers for separate collection of waste near the house } \\
\hline 1 - there are no conditions at all & 35 & 59 & 67 & 54 \\
\hline 2 - bad conditions & 12 & 12 & 11 & 12 \\
\hline 3 - average conditions & 21 & 14 & 9 & 14 \\
\hline 4 - good conditions & 14 & 8 & 4 & 9 \\
\hline 5 - excellent conditions & 17 & 6 & 7 & 10 \\
\hline Found it difficult to answer & 0 & 1 & 2 & 1 \\
\hline \multicolumn{5}{|c|}{ Reasonable amount of time for the delivery of household waste to special points or separate containers } \\
\hline 1 - there are no conditions at all & 32 & 52 & 62 & 49 \\
\hline 2 - bad conditions & 17 & 12 & 12 & 14 \\
\hline 3 - average conditions & 20 & 17 & 10 & 16 \\
\hline 4 - good conditions & 12 & 6 & 5 & 7 \\
\hline 5 - excellent conditions & 13 & 6 & 4 & 8 \\
\hline Found it difficult to answer & 6 & 7 & 7 & 6 \\
\hline \multicolumn{5}{|c|}{ Timely and correct waste disposal } \\
\hline 1 - there are no conditions at all & 27 & 44 & 56 & 43 \\
\hline 2 - bad conditions & 13 & 14 & 14 & 13 \\
\hline 3 - average conditions & 22 & 19 & 11 & 17 \\
\hline 4 - good conditions & 16 & 11 & 6 & 11 \\
\hline 5 - excellent conditions & 19 & 8 & 9 & 12 \\
\hline Found it difficult to answer & 3 & 4 & 4 & 4 \\
\hline \multicolumn{5}{|c|}{ Awareness of the population about what can be sorted and how? What is the correct way to do so? } \\
\hline 1 - there are no conditions at all & 43 & 63 & 69 & 59 \\
\hline 2 - bad conditions & 19 & 14 & 12 & 15 \\
\hline 3 - average conditions & 16 & 12 & 8 & 12 \\
\hline 4 - good conditions & 10 & 4 & 3 & 6 \\
\hline 5 - excellent conditions & 10 & 5 & 4 & 6 \\
\hline Found it difficult to answer & 2 & 2 & 4 & 2 \\
\hline
\end{tabular}

Total: The level of conducive environment development

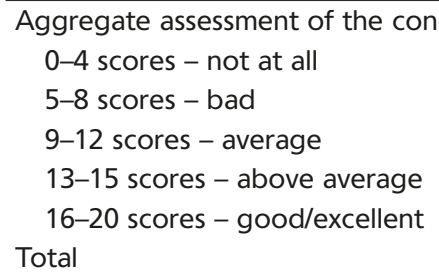

situation supported (which is important) by the control and promotion of its results on the Internet by the initiative citizens (for example, tracking the divided and mixed garbage with the help of GPS beacons placed in packages). But such a social factor as the involvement of the majority of neighbors in the SCHW, as a condition for involving the respondent, has increased its role everywhere, especially in the group of potential participants. Probably, the "effect of the participation of similar others" is increasing, and the more noticeable the SCHW is, ceteris paribus, the more potential participants will become actual participants, and the pace of development of the practice will increase.

So, we acknowledge that the main (and increasing) part of Russians today does not refuse to participate in the SCHW, but puts forward counter requests to the authorities and 
Conditions for involvement (continued participation) in the SCHW (in \% by column)

\begin{tabular}{|c|c|c|c|c|c|c|c|c|}
\hline \multirow{2}{*}{ Conditions } & \multicolumn{2}{|c|}{ Actual } & \multicolumn{2}{|c|}{ Potential } & \multicolumn{2}{|c|}{ Indifferent } & \multicolumn{2}{|c|}{ Total } \\
\hline & 2017 & 2020 & 2017 & 2020 & 2017 & 2020 & 2017 & 2020 \\
\hline $\begin{array}{l}\text { Installation of containers for the SCHW near the } \\
\text { house }\end{array}$ & 79 & 77 & 89 & 79 & 61 & 42 & 69 & 64 \\
\hline $\begin{array}{l}\text { The availability of information about what can be } \\
\text { sorted and how; how to do it correctly }\end{array}$ & $x$ & 35 & $x$ & 41.5 & $x$ & 19 & $x$ & 30 \\
\hline $\begin{array}{l}\text { Confidence that the separately collected waste } \\
\text { will be recycled }\end{array}$ & 30 & 25 & 32.5 & 24 & 24 & 17 & 26 & 21.5 \\
\hline $\begin{array}{l}\text { Participation of the majority of neighbors in the } \\
\text { SCHW }\end{array}$ & 17 & 22 & 12 & 21 & 12 & 15 & 13 & 19 \\
\hline $\begin{array}{l}\text { Reasonable amount of time for the delivery of } \\
\text { waste to special points or separate containers }\end{array}$ & 20 & 23 & 15 & 21 & 17 & 9 & 17 & 17 \\
\hline $\begin{array}{l}\text { Introduction of fines or additional fees for refusal } \\
\text { to sort }\end{array}$ & 13 & 16 & 11.5 & 16 & 10 & 10.5 & 11 & 14 \\
\hline $\begin{array}{l}\text { Availability of information about where you can } \\
\text { take separately collected waste }\end{array}$ & 15 & 16 & 21 & 15.5 & 15 & 9 & 16 & 13 \\
\hline Organization of timely and correct waste disposal & 20 & 13 & 23 & 20 & 17 & 7 & 19 & 12 \\
\hline
\end{tabular}

businesses to create an accessible and convenient infrastructure. Advances in its development over the past two years have affected the jump-like growth in the number of actual participants in the SCHW, an increase in potential ones and a sharp decrease in indifferent ones. However, the group of indifferent people is becoming more and more "intractable": it is less receptive to positive changes in the development of a supportive environment and less often calls them as a condition for its implementation. In addition, judging by the assessments of individual components of the contributing environment by different groups, in the future, if the status quo is maintained, some rollback and an increase in the number of those who are disappointed in the SCHW is possible. Among the bottlenecks there are not only the lack of a convenient infrastructure, which fixes the majority of both potential participants and indifferent ones, but also the weak awareness of all groups about what and how to sort, how to do it correctly, and also what is the effect of the efforts they have already made.

Factors of inclusion in the SCHW: regression analysis. As far as can be judged by the multinomial logistic regression ratios, the Russians, ceteris paribus, are more likely to be actual participants in the SCHW than taking an indifferent position if they are concerned about the severity of the garbage problem, take a constructive position regarding the SCHW as a way to weaken it, positively assess the current level of the conducive environment for the SCHW, want to be personally responsible for the state of the environment (both without looking back, and with an eye to the actions/assessments of other people), have participated in some kind of financial help to random people in the last year. But for the majority of objective individual characteristics (social and age, status), the actual participants do not differ from indifferent ones. The exception is the age: millennials and pensioners are more common among the actual participants. Similar differences from the indifferent ones are also a characteristic of the potential participants, but there are also certain specifics. Against the background of the disappearance of differences in relation to high assessments of the level of development of the conducive environment, the belief in the influence on the solution of an important problem (the efforts made are not useless) begins to play a significant role.

Due to the fact that the ratios of the multinomial regression $\beta$ do not lend themselves to the direct interpretation as a measure of influence, Table 6 shows the average marginal effects calculated on their basis for each position in relation to the SCHW. These demonstrate the average percentage point (p.p.) change in the probability of the corresponding outcome after a particular independent variable is changed its value by 1 unit, provided all other independent variables remain unchanged. 
The strongest positive relationship exists between involvement in the $\mathrm{SCHW}$ and assessments of the level of development of the conducive environment. The higher this score, the higher the probability of getting into the group of actual participants. So, in comparison with those who indicated a complete lack of conditions for the SCHW in their locality/yard (0-4 points, Table 4), the probability of including those who gave these conditions an average value (9-12 points) is higher by 29.6 p.p., and a good or excellent (16-20 points) is 37.2 p.p.

The second group of significant factors is related to motives and attitudes. Pro-environmental and prosocial motives combined in the "green moral index" (Table. 3), are closely associated with getting into the group of actual participants (the probability is higher by 12-14 percentage points compared to those who have zero index). Nevertheless, the role of moral aspirations is less than the level of development of the conducive environment ( $H 1$ hypothesis is not rejected). In addition, the changes noted above in the structure of the "green moral index" (a decrease in the significance of two components out of four in 2020) also affected the nature of relationship between the actual involvement in the SCHW and the index value (Table 6). $\mathbf{H} 2$ hypothesis stating that the prosocial and pro-environmental motives are more associated with the probability of actual involvement than the motives of personal advantage is not rejected only partially. Indeed, the motive for obtaining personal pleasure/satisfaction from participation in the SCHW, as before, is insignificant, and personal economic benefits is of little significance $(p<0.1)$. But the role of creating the impression of a responsible person suddenly "gained momentum". Compared with those who did not indicate this motive, the probability of involvement in the SCHW of those who indicated it is on average 20.5 percentage points higher, i.e. exceeds the individual values of the "green moral index". Probably, the actual participation today is affected not only by education and awareness in this area, but also by the participation in the SCHW of a "critical mass" from the social environment of individuals.

The level of concern about the severity of the garbage problem in Russia is positively associated with the probability of getting into the group of actual participants (the higher it is, the higher this probability is: by 6.8 and 9.9 percentage points, Table 6). Such a dependence is also characteristic of

Table 6

Average marginal effects of choosing the type of participation in the SCHW for the model of multinomial logistic regression

\begin{tabular}{|c|c|c|c|}
\hline Independent variables & Actual & Potential & Indifferent \\
\hline \multicolumn{4}{|c|}{ Assessment of the level of development of conditions for the SCHW in a locality (0-4 points-base) } \\
\hline Bad (5-8 points) & $\begin{array}{c}0.073 * * * \\
(0.024)\end{array}$ & $\begin{array}{c}0.000 \\
(0.026)\end{array}$ & $\begin{array}{c}-0.073 * * * \\
(0.026)\end{array}$ \\
\hline Average (9-12 points) & $\begin{array}{c}0.204 * * * \\
(0.028)\end{array}$ & $\begin{array}{l}-0.040 \\
(0.028)\end{array}$ & $\begin{array}{c}-0.164 * * * \\
(0.028)\end{array}$ \\
\hline Above average (13-15 points) & $\begin{array}{c}0.296 * * * \\
(0.040)\end{array}$ & $\begin{array}{c}-0.054 \\
(0.037)\end{array}$ & $\begin{array}{c}-0.242 * * * \\
(0.035)\end{array}$ \\
\hline Good or excellent (16-20 points) & $\begin{array}{c}0.372 * * * \\
(0.041)\end{array}$ & $\begin{array}{c}-0.143 * * * \\
(0.034)\end{array}$ & $\begin{array}{c}-0.229 * * * \\
(0.037)\end{array}$ \\
\hline \multicolumn{4}{|c|}{ Values-based orientations, attitudes, motives for inclusion (readiness to join) } \\
\hline \multicolumn{4}{|c|}{ 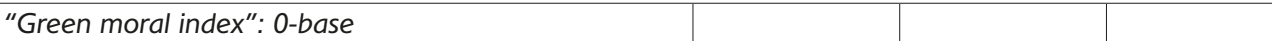 } \\
\hline 1 & $\begin{array}{c}0.119 * * * \\
(0.024)\end{array}$ & $\begin{array}{c}0.173 * * * \\
(0.022)\end{array}$ & $\begin{array}{c}-0.292 * * * \\
(0.026)\end{array}$ \\
\hline 2 & $\begin{array}{c}0.145 * * * \\
(0.032)\end{array}$ & $\begin{array}{c}0.201 * * * \\
(0.032)\end{array}$ & $\begin{array}{c}-0.346 * * * \\
(0.035)\end{array}$ \\
\hline $3-4$ & $\begin{array}{c}0.131 * * * \\
(0.039)\end{array}$ & $\begin{array}{c}0.260 * * * \\
(0.041)\end{array}$ & $\begin{array}{c}-0.391 * * * \\
(0.041)\end{array}$ \\
\hline $\begin{array}{l}\text { I want to give people the impression of myself as a } \\
\text { responsible person }\end{array}$ & $\begin{array}{l}0.205 * * * \\
(0.034)\end{array}$ & $\begin{array}{c}0.053 \\
(0.036)\end{array}$ & $\begin{array}{l}-0.258 * * * \\
(0.045)\end{array}$ \\
\hline $\begin{array}{l}\text { It is economically beneficial for me personally } \\
\text { (my family) }\end{array}$ & $\begin{array}{c}0.061 * * \\
(0.031)\end{array}$ & $\begin{array}{c}0.011 \\
(0.032)\end{array}$ & $\begin{array}{c}-0.072 * * \\
(0.034)\end{array}$ \\
\hline $\begin{array}{l}\text { I believe that my efforts are not in vain, and I can } \\
\text { influence the solution of an important problem }\end{array}$ & $\begin{array}{c}0.004 \\
(0.030)\end{array}$ & $\begin{array}{c}0.061 * * \\
(0.028)\end{array}$ & $\begin{array}{c}-0.065 * * \\
(0.033)\end{array}$ \\
\hline
\end{tabular}


End of Table 6

\begin{tabular}{|c|c|c|c|}
\hline Independent variables & Actual & Potential & Indifferent \\
\hline \multicolumn{4}{|c|}{$\begin{array}{l}\text { Level of concern about the garbage problem in Russia (base - does not bother } \\
\text { (at all or rather) or did not think about it) }\end{array}$} \\
\hline Very concerned & $\begin{array}{l}0.099 * * * \\
(0.028)\end{array}$ & $\begin{array}{c}0.022 \\
(0.028)\end{array}$ & $\begin{array}{l}-0.121 * * * \\
(0.027)\end{array}$ \\
\hline Rather concerned & $\begin{array}{c}0.068 * * \\
(0.027)\end{array}$ & $\begin{array}{l}-0.009 \\
(0.027)\end{array}$ & $\begin{array}{l}-0.058 * * \\
(0.026)\end{array}$ \\
\hline
\end{tabular}

Ideas about the need to introduce the SCHW in Russia (the basic judgment is "This is an urgent task, it is necessary to create conditions for its solution as soon as possible")

\begin{tabular}{|c|c|c|c|}
\hline $\begin{array}{l}\text { "I recognize the importance, but I do not believe in } \\
\text { its success. All previous attempts have failed" }\end{array}$ & $\begin{array}{c}-0.088 * * * \\
(0.025)\end{array}$ & $\begin{array}{c}0.003 \\
(0.025)\end{array}$ & $\begin{array}{c}0.085 * * * \\
(0.025)\end{array}$ \\
\hline $\begin{array}{l}\text { "The problem is important, but our people are not } \\
\text { yet ready to separate household waste" }\end{array}$ & $\begin{array}{l}-0.139 * * * \\
(0.025)\end{array}$ & $\begin{array}{l}0.005 \\
(0.025)\end{array}$ & $\begin{array}{c}0.134 * * * \\
(0.026)\end{array}$ \\
\hline $\begin{array}{l}\text { "Russia does not need the separate garbage } \\
\text { collection at all"/have never thought about it/it makes } \\
\text { no difference }\end{array}$ & $\begin{array}{l}-0.161 * * * \\
(0.046)\end{array}$ & $\begin{array}{l}-0.016 \\
(0.046)\end{array}$ & $\begin{array}{c}0.177 * * * \\
(0.043)\end{array}$ \\
\hline \multicolumn{4}{|c|}{ Social, age and status characteristics } \\
\hline \multicolumn{4}{|l|}{ Age: $18-30$ years - base } \\
\hline $31-40$ years & $\begin{array}{l}0.051^{*} \\
(0.030)\end{array}$ & $\begin{array}{c}0.030 \\
(0.029)\end{array}$ & $\begin{array}{c}-0.081 * * * \\
(0.029)\end{array}$ \\
\hline $51-60$ years & $\begin{array}{l}-0.007 \\
(0.032)\end{array}$ & $\begin{array}{l}0.060^{*} \\
(0.032)\end{array}$ & $\begin{array}{c}-0.053^{*} \\
(0.032)\end{array}$ \\
\hline older than 60 & $\begin{array}{c}0.051 \\
(0.031)\end{array}$ & $\begin{array}{l}0.056^{*} \\
(0.031)\end{array}$ & $\begin{array}{c}-0.107 * * * \\
(0.030)\end{array}$ \\
\hline \multicolumn{4}{|c|}{ Prosocial activity in other areas } \\
\hline $\begin{array}{l}\text { Monetary contributions for the last year, including } \\
\text { alms }\end{array}$ & $\begin{array}{l}0.064 * * * \\
(0.021)\end{array}$ & $\begin{array}{c}0.004 \\
(0.021)\end{array}$ & $\begin{array}{l}-0.067 * * * \\
(0.020)\end{array}$ \\
\hline $\begin{array}{l}\text { Transfer of unnecessary things and other items to } \\
\text { other people on a regular basis }\end{array}$ & $\begin{array}{l}-0.090 * * * \\
(0.021)\end{array}$ & $\begin{array}{c}0.041 * * \\
(0.021)\end{array}$ & $\begin{array}{c}0.048 * * \\
(0.021)\end{array}$ \\
\hline
\end{tabular}

Notes. $N=2000$. Regions (8 federal districts) are controlled. ${ }^{*} p<0.1,{ }^{*} p<0.05,{ }^{*} * * p<0.01$. Robust standard errors are given in parentheses. Probability $>\chi^{2}=0,0000$. Pseudo $R^{2}=0.1899$. The table does not show the variables that turned out to be insignificant: gender, age 41-50 years, education, financial status of the family, type of settlement, getting personal pleasure from being involved in the SCHW case, participation in volunteer work over the past year, membership in the non-profits and participation in their activities.

the position regarding the SCHW as a way to mitigate the garbage problem, although the connection with the probability of involvement is weakened due to the disbelief of individuals in the success of this venture, the confidence that "our people are not ready to separate the household waste", as well as due to the position that the SCHW as such is unnecessary in Russia. Thus, $\mathbf{H} 4$ hypothesis is not rejected in this part. But in relation to the potential participants, it was not confirmed. Currently, the values of the "green moral index" are most associated with the probability of falling into this group (increasing it by 17-26 percentage points). The motives of the personal advantage (both economic and non-economic), as before, are insignificant. Obviously, the potential participants do not expect any incentives or sanctions from the environment. At the same time, they, unlike the actual participants, have higher aspirations for the conditions of "involvement" in the SCHW: they give significance to the non-uselessness (efficiency) of the efforts made and have higher requirements for the "onetime" development of the conducive environment, which reduces the costs of their participation ( $\mathrm{H} 3$ hypothesis is not rejected in this part). It is no coincidence that all ratings of the conducive environment, below good/excellent, are not associated with the probability of getting into the group of potential participants, and the highest ratings, reducing the probability of getting into the group of potential participants (by 14 p.p.), "push" them into the group of actual participants. 
It is noteworthy that getting into groups with different positions in relation to the SCHW is now significantly not related to either gender or status (education, type of settlement, material status of the family) characteristics of individuals. Compared to 2017, the differences between men and women, as well as between individual types of settlements, have disappeared. If at first women were more actively involved in the SCHW than men, then as the group expanded, the differences on this basis were leveled. A similar effect was caused by a headway in the development of the SCHW infrastructure in different types of settlements in 2019-2020, including Moscow, which previously lagged behind other million cities on this basis [Shabanova, 2019: 104].

There is a persistent lack of connection between the position in relation to the SCHW and membership/participation in the activities of non-profits. However, $\mathrm{H} 5$ hypothesis about a positive relationship between voluntary involvement in the SCHW and other voluntary socio-economic activities (monetary donations, voluntary labor, transfer of things), both through non-profits and through informal civil structures, is not rejected only partially. Those who made monetary donations in the last year, the probability of getting into the group of actual participants of the $\mathrm{SCHW}$ is 6.3 percentage points higher compared to those who did not make them during this period. On the contrary, this value is 9.1 percentage points lower with those who gave away unneeded things as compared to those who did not give them away. It can be assumed that this connection is temporary, connected both directly with the pandemic and with the effect of "moral licensing" that it aggravates: people refrain from being involved in new behaviors to mitigate a particular problem if they believe that they have already made a feasible contribution and can "rest on their laurels" [Truelove et al., 2014; Thogersen, Crompton, 2009]. The development of infrastructure for the SCHW which came in the year of the pandemic, partially mitigated the negative consequences of the narrowing of institutional opportunities for transfer of things (suspension of the work of a number of non-profits, charity shops, fear of interacting with strangers, etc.), as well as the feeling of guilt from throwing them away. But the connection with participation in volunteering has disappeared completely against the background of a sharp decrease in the share of volunteers in all groups amidst the pandemic.

Thus, despite the preservation of the key factors of inclusion in the SCHW, the significant changes have occurred in their structure, both related to the progress in the development of the conducive environment in 2019-2020, and to the challenges from the 2020 pandemic.

Conclusions and final considerations. The Russians promptly responded to the advances made by the government and businesses in the development of the SCHW conducive environment. The group of actual participants in 2020 has significantly expanded, which once again confirms the conclusion we made earlier (according to data of 2017) that the population is not a weak link in the social mechanism of the SCHW formation [Shabanova, 2019: 107]. However, the group of voluntary participants has changed not only quantitatively, but also qualitatively. Pragmatists of the second wave joined the pioneer enthusiasts, who were often involved in the SCHW not because of the presence of a favorable environment, but despite its absence. As a result, the infrastructural and institutional factors came to the fore, ahead of pro-environmental and prosocial motives and attitudes, and the share of those who were disappointed in the experience increased.

As for potential participants, getting into their group is currently most strongly associated with proenvironmental /prosocial motives and attitudes. This connection has become even stronger among them than in the group of actual participants, which was not the case in 2017. Insensitivity to the level of development of the conducive environment, estimated below good or excellent, indirectly indicates a wait-and-see attitude and higher requirements of potential participants. This is also signaled by such a distinctive factor of this group, which retains a stable significance (2017 and 2020), as the utility of the efforts made, faith in the ability to influence the solution of an important problem. This indicates that a further increase in the number of participants in the SCHW is associated with setting a high bar, which implies a comprehensive progress in the development of a conducive environment. We are talking not only about installation of containers near houses, but also about an acceptable time for the 
delivery of household waste to these containers or to special points; timely and correct waste removal, as well as raising public awareness about what and how it can be sorted, how to do it correctly. The lack of this knowledge is now recorded by the representatives of all groups, regardless of their position in relation to the SCHW.

The progress in the development of the accessible and convenient infrastructure, which found a response from a very significant part of Russians, partially smoothed the aggravation of the garbage problem in connection with the pandemic. Since actual participants do not differ from the indifferent ones by the majority of social, demographic and status characteristics (gender, education, financial status of the family, type of settlement), and the number of such characteristics grew in 2020, voluntary inclusion in the SCHW, in fact, represents what Micheletti calls an individualized collective actions [Micheletti, 2003: 24-32]. However, the very fact that these actions can occur outside of traditional structures does not mean that the latter do not affect them: infrastructural and institutional factors play a significant role. The lack of connection with membership in non-profits also does not indicate the passive role of the latter in the formation of such actions: it manifests itself at the stages of both their preparation and implementation (informing, education, promotion of infrastructure development, including through interaction with other concerned parties).

Nevertheless, acting as an arena for the independent construction of identities related to the environmental or social problems that seem urgent to the individuals and fall into the area of their personal responsibility, new voluntary consumer practices indicate that the consumption increasingly becomes the sphere of modern civil society, expanding its boundaries and strengthening its social and economic role.

\section{REFERENCES}

Заславская Т.И. Современное российское общество: социальный механизм трансформации. М.: Дело, 2004. [Zaslavskaya T.І. (2004) Modern Russian Society: Social Transformation Mechanism. Moscow: Delo. (In Russ.)]

Шабанова М.А. Раздельный сбор бытовых отходов в России: уровень, факторы и потенциал включения населения // Мир России. 2019. Т. 28. № 3. С. 88-112. [Shabanova M. (2019) Separate Waste Collection in Russia: The Level, Factors and Potential for Citizen Engagement. Mir Rossii [Universe of Russia]. Vol. 28. No. 3: 88-112. (In Russ.)] DOI: 10.17323/1811-038X-2019-28-3-88-112.

Штомпка П. Социология социальных изменений. М.: Аспект Пресс, 1996. [Sztompka P. (1996) The Sociology of Social Change. Moscow: Aspekt-Press.]

Berglund C. (2006) The Assessment of Households' Recycling Costs: The Role of Personal Motives. Ecological Economics. Vol. 56. No. 4: 560-569. DOI: 10.1016/j.ecolecon.2005.03.005.

Czajkowski M., Hanley N., Nyborg K. (2017) Social Norms, Morals and Self-interest as Determinants of Proenvironment Behaviours: The Case of Household Recycling. Environmental and Resource Economics. Vol. 66. No. 4: 647-670. DOI: 10.1007/s10640-015-9964-3.

Etzioni A. (2003) Toward a New Socio-economic Paradigm. Socio-Economic Review. Vol. 1. No. 1: 105-118. DOI: 10.1093/soceco/1.1.105.

Filho W., Voronova V., Kloga M., Paço A., Minhas A., Salvia A., Ferreira C., Sivapalan S. (2021) COVID-19 and Waste Production in Households: A Trend Analysis. Science of the Total Environment. Vol. 777. Article no. 145997. DOI: 10.1016/j.scitotenv.2021.145997.

Giudice F., Caferra R., Morone P. (2020) COVID-19, the Food System and the Circular Economy: Challenges and Opportunities. Sustainability. Vol. 12. No. 19. Article no. 7939. DOI: 10.3390/su12197939.

Hantoko D., Li X., Pariatamby A., Yoshikawa K., Horttanainen M., Yan M. (2021) Challenges and Practices on Waste Management and Disposal during COVID-19 Pandemic. Journal of Environmental Management. Vol. 286. Article no. 112140. DOI: 10.1016/j.jenvman.2021.112140.

Hobbs J.E. (2020) Food Supply Chains during the COVID-19 Pandemic. Canadian Journal of Agricultural Economics. Vol. 68. No. 2: 171-176. DOI: 10.1111/cjag.12237.

Hoornweg D., Bhada-Tata B.P. (2012) What a Waste: A Global Review of Solid Waste Management. Urban Development Series Knowledge Papers. No. 15. Washington: The World Bank. URL: https://www.ccacoalition.org/en/resources/what-waste-global-review-solid-waste-management-urbandevelopmentseries-knowledge-papers (accessed 19.04.2021). 
Ikiz E., Maclaren V.W., Alfred E., Sivanesan S. (2021) Impact of COVID-19 on Household Waste Flows, Diversion and Reuse: The Case of Multi-residential Buildings in Toronto, Canada. Resources, Conservation and Recycling. Vol. 164. Article no. 105111. DOI: 10.1016/j.resconrec.2020.105111.

Iyer E.S., Kashyap R.K. (2007) Consumer Recycling: Role of Incentives, Information, and Social Class. Journal of Consumer Behaviour. Vol. 6. No. 1: 32-47. DOI: 10.1002/CB.206.

Kirakozian A. (2016) The Determinants of Household Recycling: Social Influence, Public Policies and Environmental Preferences. Applied Economics. Vol. 48. No. 16: 1481-1503. DOI: 10.1080/00036846.2015.1102843.

Miafodzyeva S., Brandt N. (2013) Recycling Behaviour among Householders: Synthesizing Determinants via a Meta-analysis. Waste and Biomass Valorization. Vol. 4. No. 2: 221-235. DOI: 10.1007/ s12649-012-9144-4.

Micheletti M. (2003) Political Virtue and Shopping: Individuals, Consumerism, and Collective Action. New York: Palgrave Macmillan.

Owusu V., Adjei-Addo E., Sundberg C. (2013) Do Economic Incentives Affect Attitudes to Solid Waste Source Separation? Evidence from Ghana. Resources, Conservation and Recycling. Vol. 78: 115-123. DOI: 10.1016/J.RESCONREC.2013.07.002.

Pappalardo G., Cerroni S., Nayga R.M. Jr., Yang W. (2020) Impact of COVID-19 on Household Food Waste: The Case of Italy. Frontiers in Nutrition. Vol. 7. Article no. 585090. DOI: 10.3389/fnut.2020.585090.

Principato P., Secondi L., Cicatiello C., Giovanni M. (2020) Caring More about Food: The Unexpected Positive Effect of the COVID-19 Lockdown on Household Food Management and Waste. Socio-Economic Planning Sciences. Article no. 100953. DOI: 10.1016/j.seps.2020.100953. (In press.)

Robinson G.M., Read A.D. (2005) Recycling Behavior in London Borough: Results from Large-scale Household Surveys. Resources, Conservation and Recycling. Vol. 45. No. 1: 70-83. DOI: 10.1016/j. resconrec.2005.02.002.

Shaw P.J., Maynard S.J. (2008) The Potential of Financial Incentives to Enhance Householders' Curbside Recycling Behavior. Waste Management. Vol. 28. No. 10: 1732-1741. DOI: 10.1016/j. wasman.2007.08.008.

Thogersen J., Olander F. (2003) Spillover of Environment-friendly Consumer Behavior. Journal of Environmental Psychology. Vol. 23. No. 3: 225-236. DOI: 10.1016/S0272-4944(03)00018-5.

Truelove H.B., Carrico A.R., Weber E.U., Raimi K.T., Vandenbergh M.P. (2014). Positive and Negative Spillover of Pro-environmental Behavior: An Integrative Review and Theoretical Framework. Global Environmental Change. Vol. 29: 127-138. DOI: 10.1016/j.gloenvcha.2014.09.004.

UNSCN. (2020) COVID-19 Pandemic: The Evolving Impact on How People Meet the Food System. URL: https://www.unscn.org/en/news-events/recent-news?idnews=2065 (accessed 19.04.2021). 